Contents available at: Sri Lanka Journals Online

\title{
Behavioral Factors Influencing the Adoption of 1/2S d/2 Tapping System by Smallholder Rubber Farmers in Moneragala District
}

\author{
P.K.K.S. Gunarathne ${ }^{1 *}$, H.V.A. Wikramasuriya ${ }^{1}$, M.W.A.P. Jayathilaka ${ }^{1}$ and W. Wijesuriya ${ }^{2}$ \\ ${ }^{1}$ Postgraduate Institute of Agriculture, University of Peradeniya, Sri Lanka \\ ${ }^{2}$ Rubber Research Institute of Sri Lanka, Agalawatta, Sri Lanka
}

\section{ARTICLE INFO}

\section{Article history:}

Received: 20 June 2021

Revised version received: 6 September 2021

Accepted: 18 October 2021

Available online: 01 January 2022

\section{Keywords:}

Adoption

Rubber smallholders

S2D2 tapping system

\section{Citation:}

Gunarathne, P.K.K.S., Wikramasuriya, H.V.A., Jayathilaka, M.W.A.P., and Wijesuriya, W. (2022). Behavioral Factors Influencing the Adoption of S2D2 Tapping System by Smallholder Rubber Farmers in Moneragala District. Tropical Agricultural Research, 33(1): 40-48.

DOI: http://doi.org/10.4038/tar.v33i1.8524

Gunarathne, P.K.K.S

https://orcid.org/0000-0002-2341-5618

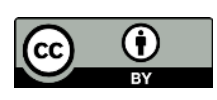

\section{ABSTRACT}

The adoption of the $1 / 2 \mathrm{~S} d / 2$ tapping system by rubber smallholders is far behind the expectation of the Rubber Research Institute of Sri Lanka in Moneragala District. This study has assessed the behavioral factors that influence the adoption of the $1 / 2 \mathrm{~S} d / 2$ tapping system. Data were collected using stratified random sampling. A self-administrated survey was deployed among rubber smallholders (self-tappers) in Moneragala District during 2020. The conceptual model was developed based on the decomposed theory of planned behavior. Study variables were measured using validated research instruments. A two-stage model-building process was applied. The conceptualized model was tested empirically, using partial least square structural equation modeling (SMART- PLS 3.2 version). The composite six-predictor conceptual framework and structural model explained $79 \%$ of the variance in the adoption of the $1 / 2 \mathrm{~S} d / 2$ tapping system by rubber smallholders. The adoption of $1 / 2 \mathrm{~S} d / 2$ by rubber smallholders positively correlated with the behavioral factors, behavioral intention, and perceived behavioral control. There were positive relationships between; compatibility and attitude, relative advantage and attitude, perceived usefulness and attitude, perceived ease of use and attitude, subjective norms and behavioral intention, facilitating condition, and perceived behavioral control. These findings can help boost the behavioral intention of rubber smallholders in Moneragala District in using $1 / 2 \mathrm{~S} \mathrm{~d} / 2$, especially by improving the aspects of attitude and subjective norms of tappers.

\footnotetext{
* Corresponding author: kapila.s.gunarathne@gmail.com
} 


\section{INTRODUCTION}

The rubber (Hevea brasiliensis) sector is the second largest foreign exchange earner in Sri Lanka in terms of export earnings and employment generation in the plantation sector and has contributed to $0.2 \%$ of the GDP in 2020 (CBSL, 2020). Rubber is a popular crop among the smallholders who cultivate extents less than 20.2 ha in Sri Lanka. The smallholder rubber sector is considered the most dynamic segment of the rubber sector since it represents $59 \%$ of the total rubber extent of Sri Lanka and has contributed to $48 \%$ of the national rubber production in 2019 (MPI, 2019). Moneragala District $\left(6.7563^{\circ} \mathrm{N}\right.$ and $81.2519^{\circ} \mathrm{E}$ ) is the second-largest district in Sri Lanka with an extent of 565,930 ha of which $12 \%$ is under the agricultural sector, with about $5 \%$ of cultivable lands utilized for permanent crops (Dissanayake et al., 2016). Moneragala has wet, intermediate, and dry climatic conditions and many agro-ecological regions. Of them, IL1c, IL2, and IM2b, distributed among eight Divisional Secretariat (DS) divisions, are utilized for rubber cultivation (Wijesuriya et al., 2013). At present, the total extent of rubber smallholdings in Moneragala is about 5,087 ha $(9,415$ number of holdings $)$, and Moneragala is the fifth rubber growing district according to the land extent under rubber cultivation in Sri Lanka (MPI, 2019). Latex is the main economic constituent of the rubber tree, extracted during its mature period once the harvestable girth is attained. Rubber tapping is the periodic excision of a thin shaving of the bark with a taping knife along a sloping groove placed spirally on the bark of the tree trunk to extract latex from latex vessels. The Rubber Research Institute of Sri Lanka (RRISL) is the apex body in the country, which undertakes research studies in all aspects of rubber farming and delivers extension service to the smallholder rubber sector. Many recommended farming practices have been introduced to the Moneragala area by RRISL. Of those, the 1/2S d/2 Tapping System (SDTS) was introduced to increase rubber productivity sustainably. SDTS is done in an angled half spiral cutting and on alternate days (RRISL, 2003).

Public and private sector extension services have launched many knowledge disseminations approaches to enhance the adoption level of SDTS (Gunarathne et al., 2020) in Moneragala. The statistics for Moneragala District on the level of adoption of practices in SDTS is minimum and not at a satisfactory level. There are several studies reported in the literature on rubber farming in Moneragala. For example, Wijesuriya et al., (2013) and Dissanayake et al, (2016, 2010) studied farmers' expectations, potentials, and constraints for RF in Moneragala District. However, those previous studies did not specifically focus on SDTS in Moneragala. Poor adoption of the SDTS had caused issues such as damaged trees, early uprooting, less potential yield due to poor harvesting quality, abandoning of harvestable holdings, which may lead to low national rubber production. The knowledge and the skills in harvesting recommendations are vital for improved adoption (Wijesuriya et al., 2011). The study has examined the factors that influence the adoption of SDTS by RSS in Moneragala. The findings of the study would assist in designing more effective policy instruments to remove adoption barriers of SDTS in Moneragala.

\section{METHODOLOGY}

\section{Sampling techniques}

Eight DS divisions of the Moneragala district were selected for this study. Rubber Smallholders (RSs) who have been tapping at least for five years in their mature rubber lands were selected using the stratified random sampling technique based on the distribution of rubber lands. The minimum size of the sample was 297, representing $23 \%$ of the population at a $90 \%$ confidence interval using Raosoft web-based sampling calculator (http://www.raosoft.com/samplesize.html).Strati fication was done based on the geographical distribution of RSs in all rubber growing DS divisions (8) in Moneragala. Twenty-three percent of the Grama Niladari (GN) divisions, where the highest number of RSs found within each DS division, were selected using statistical sources. The individual survey sample (23\% of RSs of each GN division) was randomly selected based on the number of RSs in each GN division.

\section{Data collection}

Both primary and secondary data were collected for this study. A pre-tested questionnaire survey was carried out in 2020 to gather the information from RSs based on the objectives of the study. The questionnaire for RSs had both key socio-economic factors and behavioral factors measuring items. A structured direct interview schedule was used in the gathering of data from RSs, by the researcher himself.

\section{Conceptualization of the study variables and their relationships}

To understand the intentions of RSs to adopt SDTS, the Decomposed Theory of Planned Behaviour 
(DTPB) was applied as a theoretical framework (Taylor and Todd, 1995). The DTPB focuses on the direct measures of Attitude (ATD), Subjective
Norms (SN), and Perceived Behavioural Control $(\mathrm{PBC})$ to predict Behavioural Intention (BI), which in turn predicts one's behavior (Ajzen, 1991).

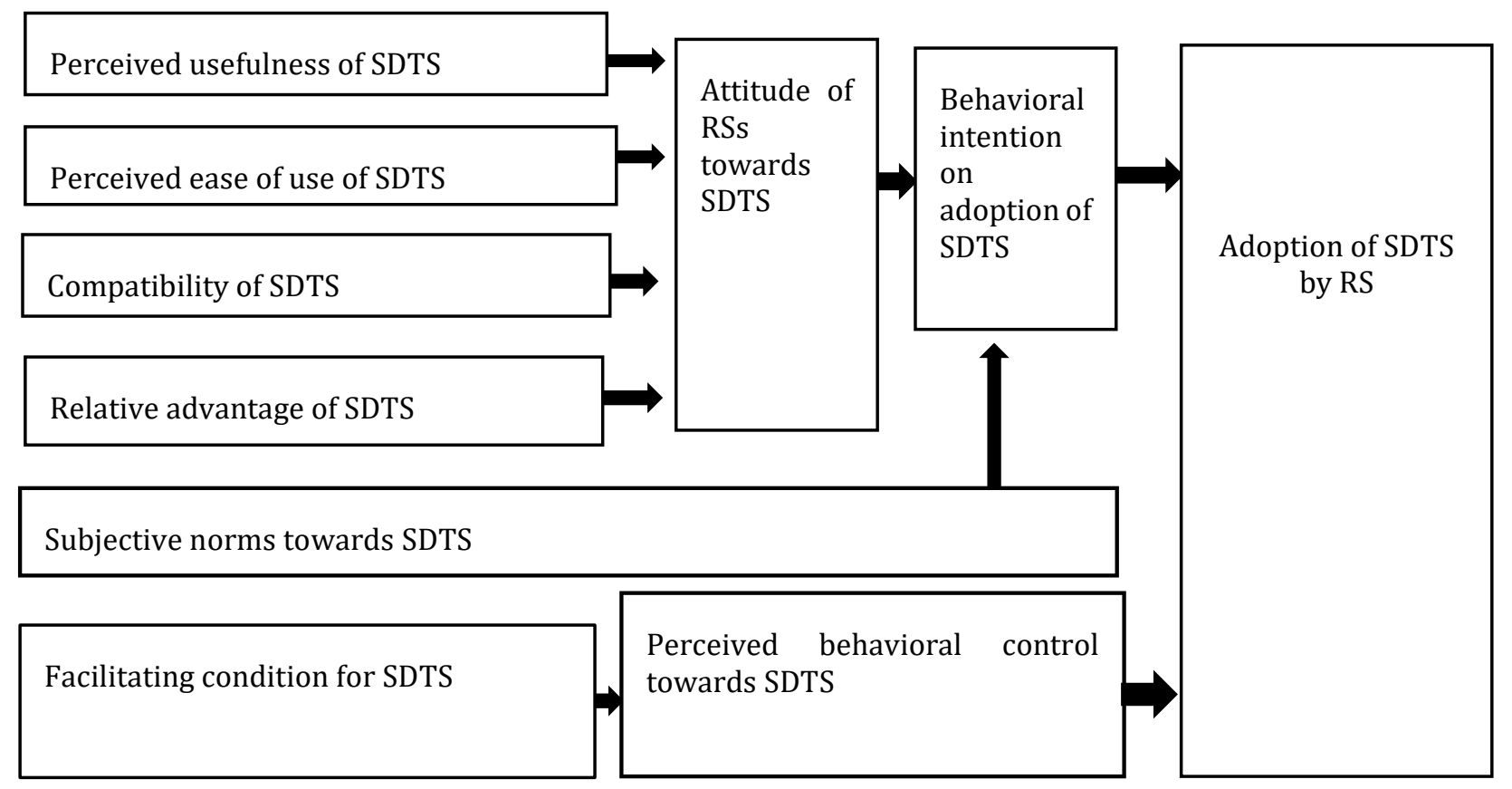

\section{Figure 1. The conceptual model of the study}

The DTPB has previously been used in many studies to find out the relationship between belief structures and intention to adopt innovations. Based on the theoretical framework and literature cited, the adoption of SDTS in the local application of the RSs is conceptualized (Figure 1).

\section{Development of hypotheses}

\section{Relative Advantage}

Relative advantage (RA) refers to the degree to which an innovation provides benefits that replace those of its precursor and may incorporate factors such as economic benefits, image, enhancement, convenience, and satisfaction. RA is a vital factor in determining the attitude for innovations (Rogers, 1983). Here, relative advantage refers to the financial advantages of SDTS.

Therefore, we proposed the hypothesis, "perceived RA towards the adoption of SDTS positively affects ATD of RSs" (H1).

\section{Compatibility}

According to Rogers (1983), Compatibility (C0) is the degree to which an innovation is perceived as being consistent with the existing values, past experiences, and needs of potential adopters. Tornatzkey and Klein (1982) find that innovation is more likely to be adopted when it is compatible with the value system of an individual. In this study, CO refers to the extent to which RSs believe that the application of SDTS would be compatible with their rubber farming practices. Therefore, we proposed a hypothesis, "perceived CO towards the adoption of SDTS positively affects ATD of RSs" (H2).

\section{Perceived Usefulness}

Perceived Usefulness (PU) is defined as a person's subjective evaluation of the extent of using a system that would enhance productivity. The attitude towards using the technology would likely become positive, with a higher PU. PU has proven to be an antecedent to attitude (Ajzen, 1991). So that, PU is positively related to attitude towards using SDTS. In the context of SDTS, PU would be the degree to which individual views that SDTS would result in more productivity than previous SDTS. Therefore, the hypothesis was proposed as the alternate hypothesis, as "PU towards the adoption of SDTS positively affects ATD of RSs" (H3).

\section{Perceived Ease of Use}

Perceived Ease of Use (PEU) is defined as the expectation by an individual of the degree to which the target system will be free from effort. Studies have proven that PEU has a direct relationship with 
attitude (Ajzen, 1991). So that the PEU will be positively related to attitude towards using SDTS. In this study, perceived ease of use refers to the level of the easiness of using SDTS introduced by the RRISL. Therefore, the hypothesis was proposed as an alternate hypothesis, as "PEU towards the adoption of SDTS positively affects ATD of RSs" (H4).

\section{Attitude}

ATD is a positive and negative feeling of an individual towards a particular object, or towards the intention of performing a particular behavior (Ajzen and Fishbein, 2000). According to Rogers (1983), ATD refers to the general feeling of an individual on favourableness or unfavourableness towards using innovation. ATD is linked to behavioral intention as individual forms psychological intentions to perform behaviors toward which they have a positive feeling. Studies have proven a significant direct relationship of ATD towards (Gopi and Ramayah, 2007) so that the ATD towards using SDTS will be positively related to the intention to use it. In this study, ATD refers to the feeling of RSs about using SDTS in their rubber cultivation. Accordingly, we proposed an alternate hypothesis, as "attitude toward the adoption of SDTS positively affects their behavioral intention of RSs" (H5).

\section{Perceived Behavioural Control}

According to Ajzen (1991), Perceived Behavioural Control (PBC) is defined as the level of confidence of an individual about their ability to perform the behavior based on the difficulty or ease, they perceive on its performance as it relates to difficulties or facilitators. It reflects beliefs regarding access to the resources and opportunities needed to affect behavior (Ajzen, 1991). $\mathrm{PBC}$ refers to the factors that may encourage the performance of the behavior. Knowledge is one of the important components of behavior and it plays a vital role in the adoption of improved technologies (Bloom et al., 1985). Knowledge becomes power to a person, so farmers' technical knowledge determines their ability to reach and find solutions. The type of skill has a relationship with the adoption of cultural practices. In this study, $\mathrm{PBC}$ refers to an adequate level of knowledge and skill of SDTS. Therefore, the hypothesis proposed as the alternate hypothesis, was "PBC of RSs positively affects on the adoption of SDTS" (H6).

\section{Facilitating conditions}

Facilitating Conditions (FC) are defined as the environmental factors that influence an individual's desire to perform a task. FC reflects the availability of resources/inputs which are needed to engage in a behavior. Such resources may include time, money, and other specialized resources needed to perform a particular behavior. Taylor and Todd (1995) showed that fewer obstacles produce a feeling of greater control and in turn, positively affect intentions to use technology. Farmers did not adopt certain management practices due to resource limitations. The contact with extension personnel has a positive relationship with innovativeness. Getting advice from extension officers was positively related to adoption among the out-grower farmers of sugarcane. One of the reasons for the nonadoption of farm innovations was that the technology developed by researchers and disseminated to farmers by extension workers did not accompany an adequate and timely supply of farm inputs. In this study, availability of inputs and advisory contacts done by extension officers and availability of training programs refers to $\mathrm{FC}$ for the behavioral intention of SDTS. Therefore, the following hypothesis was proposed as the alternate hypothesis: FC towards the use of SDTS positively affects PBC of RSs (H7).

\section{Subjective Norm}

According to Ajzen (1991), SN is defined as "the person's perception that most people who are important to him think he should, or should not, perform the behavior in question." The determinant of $\mathrm{SN}$ is the sum of normative beliefs, which reflects the perceived behavioral views or expectations of important referent individuals or groups. SN denotes that the behavior is initiated by an individual's wish to act according to the thought or action of the important referent others. Referent people, such as family members and friends, represent the expectations of other people to perform a particular behavior, thus they can potentially influence the behavior (Pantano and Di Pietro, 2012). SN has been observed to be more important in the early stages of implementation when users have limited direct experience from which to develop the AT toward the innovation. SN refers to the individual's perceptions of broad social pressure to (or not to) perform the expected behavior. Social pressure exerted by the significant "referent" others whose beliefs may be important to the individual whom the individual perceives to, (or perceives not to), support the behavior, conceives more (or less) the likelihood for the individual to perform it (Borotis and Poulymenakou, 2009). The adopter's family members, friends, and colleagues are groups that will potentially influence adoption. In this study, subjective norms towards the adoption of SDTS 
refer to the influence of extension officers, RSs, and mass media. Therefore, the following hypothesis was proposed as the alternate hypothesis; The SNs toward the adoption of SDTS positively affect their behavioral intentions of RSs (H8).

\section{Behavioural Intention}

BI is a person's subjective probability of performing a certain behavior. Intention to use is defined as "indications of how hard people are willing to try, and of how much of an effort they are planning to exert, to perform the behavior" (Ajzen, 1991). Many studies have reported a significant and strong relationship of BI being the most vital factor in predicting a decision to take a specific action (Ajzen, 1991). Considering this close relationship between intention and behavior, previous studies have used BI to predict specific behavior (Ajjan,1991). Thus, it is expected that there would be a positive relationship between intention and the actual behavior of RSs. Therefore, it is hypothesized that the behavioral intention of RSs to use SDTS positively affects their behavior leading to adoption. In this study, BI refers to the intention to apply the SDTS in the next season, regularly and to strongly recommend it to others too. Therefore, the following hypothesis was proposed as the alternate hypothesis; the behavioral intention of RSs positively affects the adoption of SDTS (H9).

\section{Adoption}

Rogers (1983) defined adoption as a decision to make full use of a new idea as the best course of action available. Accordingly, the process of adoption or innovation decision is a psychological process in which individual moves from awareness, interest, evaluation, to trial, and finally either to adopt or to reject the practice. In this context, adoption refers to the utilization and application of SDTS recommended by the RRISL.

\section{Instrument development and measurements}

Shih and Fang, (2004) and Rhodes and Courneya, (2003), reviewed to generate an initial list of items. Pre-test interviews were conducted with RSs to assess the instrument's clarity and question wordings of proposed items. PU, PEU, CO, RA, SN, PBC, and ATD have measured two items, while BI, $\mathrm{FC}$, and ADN were measured with three items. The responses of RSs to these measurement items were captured on a 5-point Likert scale, which ranged from 'strongly disagree' for which a 1 was given to 'strongly agree' for which a 5 was given, indicating the degree to which they agreed with the set of statements. A two-stage model-building process was applied for testing both measurement and structural models (Hair et al., 2013). The SMARTPLS 3.2 software was used to confirm and modify the basic hypotheses in the study.

\section{Test of measurement model}

The suitable fit for the measurement model was assessed by a communality test. The Cronbach's alpha, composite reliability, and factor outer loadings were assessed to measure the reliability, validity, and internal consistency of items respectively, for covering the convergence validity (Hulland, 1999). The average variance extracted was assessed to measure the discriminant validity of items. The Heterotrait-Monotrait ratio of correlations all the correlations $(<0.85)$ was used to assess the discriminant validity of the questionnaire suggested by Henseler et al., (2015). The measurement model was estimated using confirmatory factor analysis to test the reliability and validity of the measurement model (Schmitt, 2011).

\section{Assessment of the structural model}

After assessing the reliability and validity criteria for all reflective measurements of the research model and ensuring the integrity of the research data, SMART-PLS Algorithm was applied after determining 300 maximum iterations with a stop criterion of 7 using a path scheme to maximize the $\mathrm{R}^{2}$ value for the model endogenous latent variables (Henseler, 2015). For predictive purposes, we applied Partial Least Square Approach for the Structural Equation Modelling (PLS-SEM). The coefficient of determination $\left(\mathrm{R}^{2}\right)$, effect size $\left(\mathrm{f}^{2}\right)$, Stone-Geisser (Predictive relevance) index $\left(Q^{2}\right)$, and the path coefficients $(\beta)$ were assessed using the blindfolding procedure, which necessitates the predictive capacity measurements as suggested by Hair et al., 2013 and Henseler, 2015. The crossvalidated redundancy method was used to measure the $\mathrm{Q}^{2}$ by using a blindfolding procedure as recommended by Wong (2013) and (Sarstedt et $a l ., 2014)$. The variance inflation factor was applied to assess the Multi-collinearity and intercorrelations among the independent constructs within the structural model (inner model) (Hair, 2016). Both model goodness-of-fit indices, root mean square residual, and normed fit index (Hair et al., 2013) of the structural model were assessed to examine the model fit.

\section{Hypothesis testing}

The conceptualized model was empirically tested using PLS-SEM to evaluate the set of predictive relationships. The bootstrapping procedure was 
applied to examine $\beta$ significance which is a variance-based method used to estimate structural equation models, using Smart PLS 3.1 (Ringle, et al., 2014). The advantage of using PLS-SEM lies in the fact that no assumption on the distribution of data is needed (Chin et al., 2010). The t-statistics were used to test the statistical significance of both the indicators (outer model) and the structural model constructs (inner model). A two-tailed t-test of significance at $5 \%$ level was carried out, with $\mathrm{t}$ statistic values larger than 1.96 indicating the significance of the structural path significance tests. The results were interpreted with standardized $\beta$ and coefficients of determination (R2), with the bootstrap samples set at 5000 and the standard error at a $95 \%$ confidence level as suggested by Hair et al., 2013.

\section{RESULTS AND DISCUSSION}

\section{Sample characteristics of rubber smallholders}

The majority of the were males. Age of RSs varied from 19 to 79 years. Majority of RSs were in the age category of $>51$ years. No one had followed degree programmes or diplomas. Further, only $8 \%$ of RSs had attended tertiary level education (G.C.E. A/L). Majority of RSs (nearly $50 \%$ ) had 11 to 15 years of experience, $43 \%$ had 6 to 10 years of experience. Only $7 \%$ of the respondents had less than 5 years of experience in tapping.

\section{Key information of smallholdings}

The majority (80\%) of the smallholdings fell into the size of $1-1.5$ acres $(0.4-0.6 \mathrm{ha})$. The clone RRIC 121 had occupied $82 \%$ of the smallholder units. The prominent current harvesting panels were $\mathrm{B} 0$ 1 and $\mathrm{B} 0-2$. The average harvesting stand was 170 trees/acre. The average number of harvesting days was reported as 104 per year and average yield was $890 \mathrm{~kg} / \mathrm{ha} /$ year on dry rubber basis.

\section{Test of measurement model}

The results of communality test of all items were more than 0.40 and acceptable for suitable fit for measurement model (Hulland and Business, 1999). The cronbach alpha vales ranged from 0.79 to 0.98 , which were above the acceptable threshold of 0.70 $(\mathrm{PU}=0.851, \mathrm{PEU}=0.832, \mathrm{CO}=0.793, \mathrm{RA}=0.815, \quad \mathrm{SN}=$ 0.862, $\mathrm{FC}=0.892, \quad \mathrm{PBC}=0.865, \quad \mathrm{ATD}=0.866$, $\mathrm{BI}=0.757$ and $\mathrm{ADN}=0.986)$. The factor loading for all items (PU1 $=0.713, \mathrm{PU} 2=0.817, \mathrm{CO} 1=0.788$, $\mathrm{CO} 2=\quad 0.880, \quad$ PEU1 $=0.885, \quad$ PEU2 $=0.768$, RA1 $=0.551$, RA2 $=0.930, \mathrm{SN} 1=0.551, \mathrm{SN} 2=0.930$,
$\mathrm{FC} 1=0.815, \mathrm{FC} 2=0.522, \mathrm{FC} 3=0.816, \mathrm{PBC} 1=0.894$, $\mathrm{PBC} 2=0.854, \mathrm{ATD} 1=0.944, \mathrm{ATD} 2=0.934, \mathrm{BI} 1=$ $0.854, \mathrm{BI} 2=0.774, \mathrm{BI} 3=0.828, \mathrm{ADN} 1=0.992$, ADN2=982, ADN3=984) exceeds the recommended level of 0.6 . Composite reliability values of all items (PU $=0.740, \quad \mathrm{PEU}=0.814$, $\mathrm{CO}=0.821, \mathrm{RA}=0.645, \mathrm{SN}=0.725, \mathrm{FC}=0.768, \mathrm{PBC}=$ 0.866, $\mathrm{ATD}=0.937, \mathrm{BI}=0.861$ and $\mathrm{ADN}=0.991)$ exceeded recommended level of 0.7 (range from 0.73 to 0.99 ) (Hair et al., 2013). According to the $\alpha$ $(>0.07)$, composite reliability $(>0.7)$ and factor loading $(>0.6)$ which were greater than standard values, indicating the questionnaire had high reliability, validity and internal consistency recommended by Hair et al., 2013. Average variance extracted were in the range between 0.538 and 0.972 and average variance extracted of all items $(\mathrm{PU}=0.588, \mathrm{PEU}=0.687, \mathrm{CO}=0.697$, $\mathrm{RA}=0.538, \quad \mathrm{PBC}=0.764, \mathrm{SN}=0.584, \quad \mathrm{FC}=0.534$, $\mathrm{ATD}=0.881, \mathrm{BI}=0.674$ and $\mathrm{ADN}=0.972)$ exceeded recommended level of 0.5 (Sarstedt et al., 2014). The Heterotrait-Monotrait ratio of all correlations less than 0.85 and all the values lie within range which asserts the discriminant validity. In summary, the measurement model demonstrated adequate communality, reliability, cronbach's alpha, composite reliability and factor outer loadings, discriminant validity and fitness of model.

\section{Assessment of the structural model}

The $\mathrm{R}^{2}$ is a measure of the predictive power of a model for the dependent variables (Sarstedt et al., 2014). $R^{2}$ with a value of $0.67,0.33$ and 0.19 is considered substantial, moderate and low, respectively (Chin et al., 2010). $\mathrm{R}^{2}$ of ATD towards $\mathrm{BI}, \mathrm{BI}$ towards to ADN and PBC towards to ADN were 0.725 (Substantial), 0.689 (Substantial) and 0.416 (Moderate), respectively. The $\mathrm{R}^{2}$ of the structural model of this study was 0.795 and it was considered substantial in line with recommended value. The four exogenous variables (ATD, BI, PBC, SN) explain 79\% of the ADN of SDTS by RSs. Effect size $\left(\mathrm{f}^{2}\right)$ of $0.02,0.15$, and 0.35 indicates small, medium, and large effect, respectively (Chin et al., 2010). Four hypothesis (H5, H6, H7 and H9) are in the large effect category, whilst the rest $(\mathrm{H} 1, \mathrm{H} 2$, H3, H4 and H9) are medium effect size (Table 4). Since $\mathrm{Q}^{2}$ values for all latent variables $(\mathrm{ADN}=$ $0.762, \mathrm{ATD}=0.609, \mathrm{BI}=0.449$ and $\mathrm{PBC}=0.304$ ) of the inner model were greater than zero (Hair et al., 2013), the path model had a favorable strong predictive relevance. All of variance inflation factor values for all for the independent latent variables were less than five (PU1 $=1.033$, PU2 $=1.033$, C01 = 1.191, CO2 = 1.191, PEU1 = 1.171, PEU2 = 1.171, RA1 $=1.216$, RA2 $=1.216$, SN $1=1.044$, SN2 =1.044, $\mathrm{FC} 1=1.275, \mathrm{FC} 2=1.275, \mathrm{FC} 3=1.389, \mathrm{PBC} 1=1.389$, 
$\mathrm{PBC} 2=1.389, \quad \mathrm{ATD} 1=2.394, \quad \mathrm{ATD} 2=2.39, \mathrm{BI} 1=$ $1.818, \mathrm{BI} 2=1.314, \mathrm{BI} 3=1.700, \mathrm{ADN} 1=1.982$, ADN2=1.897, $A D N 3=1.869$ ) and fulfill the requirement of data according to the Multicollinearity test and so there was no collinearity problem according Hair et al., 2013. The recommended value of root mean square residual should not exceed 0.08 , while normed fit index value ranges from 0 to 1 , where the closer the normed fit index to 1 means better fit (Hair et al., 2017). The root mean square residual value for the study model was 0.074 and normed fit index value was approximately 0.8 . It could be concluded that both indices represent acceptable fit for the research model and a good fit. The previous analytical and statistical outcomes gave adequate answers to test research hypotheses.

Table 1: Hypothesis test results

\begin{tabular}{lllll}
\hline Hypothesis & $\begin{array}{l}\text { Path } \\
\text { coefficient }(\boldsymbol{\beta})\end{array}$ & $\begin{array}{l}\text { Standard } \\
\text { Deviation }\end{array}$ & t-value & Effect size $\left(\mathbf{f}^{2}\right)$ \\
\hline H1 & 0.115 & 0.064 & $5.224^{* *}$ & 0.155 \\
H2 & 0.368 & 6.094 & $5.611^{* *}$ & 0.300 \\
H3 & 0.063 & $5.612^{* *}$ & 0.315 \\
H4 & 0.354 & 0.065 & $3.802^{* *}$ & 0.975 \\
H5 & 0.342 & 0.067 & $3.760^{*}$ & 0.422 \\
H6 & 0.104 & $4.414^{*}$ & 0.713 \\
H7 & 0.583 & 0.057 & $5.335^{* * *}$ & 0.210 \\
H8 & 0.645 & 0.103 & $6.091^{* *}$ & 1.019 \\
H9 & 0.843 & 0.098 & & \\
\hline
\end{tabular}

Notes: ${ }^{*} \mathrm{p}<0.05 ;{ }^{* *} \mathrm{p}<0.01 ;{ }^{* * *} \mathrm{p}<0.001$

\section{Hypotheses testing}

Table 1 shows the $\beta$, t-values, and $p$-values for all hypotheses concerning the path analysis supported by empirical data using the bootstrapping method. All nine hypotheses in the conceptual model had achieved the $\beta$ standard. The results showed that RA had positive effect on attitude towards adoption of SDTS and intention to use SDTS for adopters (H1) $(\beta=0.115$, t-value = $5.224, \mathrm{p}<0.05)$. CO had positive effects on attitude towards adoption of SDTS (H2) ( $\beta=0.368$, t-value $=6.091, \mathrm{p}<0.01$ ). It reveals that RSs perceive practicing the SDTS being consistent with their existing cultural practices of RF, lifestyle and past experience. PU had positive effects on attitude toward SDTS (H3) $(\beta=0.354, \mathrm{t}$-value $=5.617, \mathrm{p}<$ $0.05)$. PEU had positive effects on attitude towards SDTS adoption (H4) ( $\beta=0.342$, t-value $=5.612, \mathrm{p}<$ 0.01 ). The importance of characteristics (RA and CO) of innovation on adoption is emphasized (Rogers, 1983). However, effects of CO on attitude towards SDTS are comparatively high. Therefore, extension personnel should emphasize the benefits in aspects of SDTS. In addition, extension personnel should provide adequate information and clearer guidance to encourage RSs to use the SDTS in their rubber lands. Eventually, extension personnel should educate RSs the benefits of SDTS, using training and awareness programmes covering rubber farming areas in Moneragala.

ATD had significant positive relationship with behavioural intention and thus supported H5 ( $\beta=$ 0.324 , t-value $=3.802, \mathrm{p}<0.01$ ). ATD was also the most influential factor that predicts intention of RSs to use SDTS in Moneragala. This result implies that if RSs have a positive attitude, they will certainly be more attracted to use SDTS. This result is in line with previous literature by Lee et al., 2007. ATD is considered as a powerful factor that motivates to develop a positive intention (RezaeiMoghaddam et al.,2005). It signifies that when attitude is favourable, that the chances of RSs to use a SDTS will definitely be increased. The $\mathrm{H}_{\mathrm{SN}}$ hypothesis results $(\beta=0.843$, t-value $=5.335, \mathrm{p}<$ 0.001 ) significantly and positively showed the influence of SN on BI. This implies that opinion of specific referent groups is also important in the development of an intention towards the use of SDTS. This result can be explained by the fact that the SDTS have been just introduced to Moneragala, and hence the knowledge of RSs remains rather limited. As a result, they may consult people from their own social environment to seek for advice in 
the process of adoption of this new SDTS. The positive relationship also denotes that, the more a person has a favourable social influence in adoption of SDTS, that the more favourable his intention would be. The НРвс hypothesis of this study that PBC affected on adoption of SDTS was positively and significantly supported $(\beta=0.583$, tvalue $=3.760, \mathrm{p}<0.05)$. The $\mathrm{H} 7$ hypothesized relationship i.e. that of $\mathrm{FC}$ and $\mathrm{PBC}$ too was seen to be positive and significant $(\beta=0.645$, t-value $=$ $4.414, \mathrm{p}<0.05)$. Hence, HFC too was supported. The H9 hypothesis of relationship of BI to ADN was significantly and positively supported too $(\beta=$ 0.396 , t-value $=6.091, \mathrm{p}<0.001$ ). As effects of SN on BI towards SDTS were comparatively higher than that of AT, policy makers should give more attention to improve the SN, which could be helped by improvement in the advisory services. Effect of PBC on ADN was seen to be comparatively higher than that of BI. This result concludes that RSs in Moneragala are likely to engage in practicing the SDTS, when they have the required resources to perform the behaviour. Therefore, the availability of necessary tapping marking stencils and skills of SDTP should be improved to enhance adoption of SDTP among the RSs in Moneragala.

\section{CONCLUSIONS}

The nine-predictor conceptualized model explained $79 \%$ of the variance in the adoption of the $1 / 2 \mathrm{~S} d / 2$ tapping system by rubber smallholders in Moneragala. The study has identified nine behavioral factors contributing to the adoption of tapping systems by rubber smallholders of Moneragala District. Perceived usefulness, perceived ease of use, compatibility, relative advantage, behavioral intention, attitude, subjective norms, facilitating condition, and perceived behavioral control that act as drivers for adoption of $1 / 2 \mathrm{~S} d / 2$ tapping system. To enhance the adoption of the $1 / 2 \mathrm{~S} d / 2$ tapping system, a favorable environment contributing to the above psychological factors should be improved among the rubber smallholder in Moneragala. Further research would be helpful to identify additional variables, which might also be significant in understanding the adoption of the $1 / 2 \mathrm{~S} d / 2$ tapping system by rubber smallholders in Moneragala.

\section{ACKNOWLEDGEMENT}

The authors are grateful to the rubber smallholders in Moneragala District for their valuable support.

\section{REFERENCES}

Ajzen, I. (1991), The theory of planned behavior. Organizational Behavior and Human Decision Processes [on line].[Accessed on 12.01.2021]. Available at http:// www.doi.org/10.1016/ 07495978(91)90020-T.

Ajzen, I., \& Fishbein, M. (2000). Attitudes and the attitude-behavior relation: Reasoned and automatic processes. In W. Stroebe \& M. Hewstone (Eds.), European Review of Social Psychology. John Wiley \& Sons, 1-28.

Bloom, M., Egalhlt, M., Farst, E., Hill, W., \& Karthwool, P.R. (1985). Taxonomy of education objectives. The cognitive domain. Longmans Green and Company, New York, 95-107.

Borotis, S., \& Poulymenakou, A. (2009), E-learning acceptance in workplace training: The case of a Greek bank. In: 17th European Conference on Information Systems (ECIS2009) [on line].[Accessed on 12.01.2021]. Available at http://www.doi.org/ECIS2009-0398.R1

Chin, W. (2010). Bootstrap Cross-validation Indices for PLS Path Model Assessment. In V. E. Vinzi, H. Wang, J. Henseler \& W. Chin (Eds.), Handbook of partial least squares: Concepts, methods and applications in marketing and related fields. Heidelberg: Springer, 312-450.

Dissanayake, D. M. A. P., Wijesuriya, Wasana., Herath, Keminda., \& Gunaratne, P. K. K. S., (2010). Socio-economic Status of Smallholder Rubber Farmers in Moneragala District, Journal of Food and Agriculture, Wayamba University of Sri Lanka, Makandura, Sri Lanka, 03 (1-2), 41-49.

Dissanayake, D. M. A. P., Gunarathna, P. K. K. S. \& Wijesuriya, W. (2016). Evaluation of farmer awareness on rubber cultivation and production technologies in major rubbergrowing areas of Sri Lanka. Sri Lanka Journal of Food and Agriculture, 02(1), 39-50.

Gopi, M., \& Ramayah, T. (2007). Applicability of theory of planned behavior in predicting intention to trade online: Some evidence from a developing country. International Journal of Emerging Markets, 2(4), 348-360.

Gunarathne P. K. K. S., Tennakoon T. M. S. P. K. \& Edirisinghe J. C (2020). Strategies for Improving Rubber Productivity in Smallholder 
Rubber Farming: A Case Study in Moneragala District of Sri Lanka. In Proceedings of the Seventh International Conference on Multidisciplinary Approaches, University of Sri Jayawardenapura, Gangodawila, Sri Lanka, 68.

Hair, J. F., Ringle, C. M., \& Sarstedt, M. (2013). Editorial-partial least squares structural equation modeling: Rigorous applications, better results and higher acceptance. Long Range Planning, 46(1-2), 1-12.

Henseler, J., Ringle, C. M., \& Sarstedt, M. (2015). A new criterion for assessing discriminant validity in variance-based structural equation modeling. Journal of the Academy of Marketing Science [on line].[Accessed on 12.01.2021]. Available at https://doi.org/10.1007/s11747014-0403-8

Hulland, J., \& Business, R. I. S. (1999). Use of partial least squares (PLS) in strategic management research: A review of four recent studies. Strategic Management Journal, 20(2), 195204.

Lee K. C., Kang, I., \& Kim, J. S. (2007). Exploring the user interface of negotiation support systems from the user acceptance perspective. Comput. Hum. Behav. 23(1), 220-239.

Pantano, E., \& Di Pietro, L. (2012), Understanding consumer's acceptance of technology-based innovations in retailing. Journal of Technology Management and Innovation [on line].[Accessed on 12.01.2021]. Available at http://www. doi.org/10.4067/S0718-272420 12000400001.

Rezaei-Moghaddam, K., Karami, E., \& Gibson, J. (2005). Conceptualizing sustainable agriculture: Iran as an illustrative case. Journal of Sustainable Agricultire, 27(3), 25-56.

Rhodes, R. E., \& Courneya, K. S. (2003). Investigating multiple components of attitude, subjective norm, and perceived control: An examination of the Theory of Planned Behaviour in the exercise domain. The British Journal of Social Psychology [on line]. [Accessed on 12.01.2021]. Available at https://doi.org/10.1348/014466603763276 162

Ringle, C., Wende, S., \& Will, A. (2014). SmartPLS Version 3.1 [on line].[Accessed on 12.01.2021]. Available at http://www.smartpls.de
Rogers, E. M. (1983), Diffusion of Innovations. 3rd ed. London: The Free Press [on line].[Accessed on 12.01.2021]. Available at http://www. doi.org/citeulike-article id:126680

Rubber Research Institute of Sri Lanka, (2003). Hand book of rubber,15-32.

Sarstedt, M., Ringle, C. M., Smith, D., Reams, R., \& Hair, J. F. (2014). Partial least squares structural equation modeling (PLS-SEM): A useful tool for family business researchers. Journal of Family Business Strategy, 5(1), 105115.

Schmitt Thomas. (2011). Current Methodological Considerations in Exploratory and Confirmatory Factor Analysis. Journal of Psycho educational Assessment [on line].[Accessed on 12.01.2021]. Available at DOI:10.1177/0734282911406653

Shih, Y. Y., \& Fang, K. (2004). The use of decomposed theory of planned behavior to study Internet banking in Taiwan. Internet Research, 14(3), 213-223.

Taylor, S., \& Todd, P. (1995). Understanding the information technology usage: A test of competing models. Information Systems Research, 6(2), 144-176.

The Central Bank of Sri Lanka. (2020). Central Bank Annual Report, Colombo 01, Sri Lanka, 25-37,

The Ministry of Plantation Industries. (2019). Plantation Sector Statistical Pocket Book, The Ministry of Plantation Industries, Sri Lanka, $100-150$

Tornatzky, L. G., \& Klein, K. J. (1982), "Innovation characteristics and innovation adoption implementation: a meta-analysis of findings", IEEE Tranactions on Engineering Management, 29, 28-45.

Wijesuriya, W., Dissanayake, D. M. A. P., Herath, H. M. L. K., \& Gunarathne, P. K. K. S. (2013). Constraints in sustainable smallholder rubber farming in the Moneragala district: Journal of the Rubber Research Institute of Sri Lanka, 91, 61-73. 